\title{
POLA ASUH ORANG TUA TERHADAP ANAK TUNA NETRA BERPRESTASI USIA SEKOLAH DASAR
}

\author{
Suci Setiarani ${ }^{1)}$, Yudhie Suchyadi ${ }^{1)}$ \\ ${ }^{1)}$ Universitas Pakuan, Pakuan, Indonesia \\ e-mail korespondensi : yudhie@unpak.ac.id
}

diterima: 14 Juli 2018; direvisi: 15 Agustus 2018; disetujui: 06 September 2018

\begin{abstract}
Parenting patterns of parenting are the ways and habits that parents do and feel by children, so the pattern will certainly be different on every parent. The aim of this research is to know the parenting pattern of the parent to the blind children with achievement of the blind student with achievement. Sample is taken by looking for SLB-A (blind) in Bogor. This research method is carried out by case study method. Data analysis is an effort done by working with data, organizing data, sorting it into manageable units, synthesizing it, finding and finding patterns, finding what is important and what is learned, and deciding what can be told to others. The result of the research about parenting pattern of the blind children with the achievement of elementary school age shows that the pattern of care is the great potential that make up the achievement of the blind child. Not only one form of parenting, but consists of several parenting patterns, including the pattern of foster democracy, laissez faire care, self-melt parenting, manipulation parenting, parenting patterns, parenting over the role and parenting consultant.
\end{abstract}

Keywords: Patterns of Care, Blind, Achievement.

\section{PENDAHULUAN}

Pendidikan adalah faktor yang paling penting dan prioritas utama yang membutuh-kan perhatian serius dari semua pihak, karena pendidikan adalah penentu kemajuan bangsa di masa depan. Tujuan dan cita-cita nasional, untuk kehidupan intelektual bangsa terkandung dalam UUD 1945. Pemerintah bersama masyarakat terus mencari pengembangan pendidikan demi terwujudnya bangsa yang mandiri, unggul dan siap menghadapi dunia globalisasi [1].

Pola asuh orang tua merupakan cara dan kebiasaan yang dilakukan orang tua dan dirasakan oleh anak, sehingga pola tersebut tentu akan berbeda pada setiap orang tua. Pola asuh yang diterapkan orang tua yang memiliki anak tuna netra dan anak normal pun dapat menjadi alasan pola asuh yang berbeda. Jika anak pada usia 6-12 tahun, biasanya orang tua yang memiliki anak normal masih bisa memberikan pola asuh yang membebaskan dan membiarkan, lain halnya dengan orang tua yang memiliki anak tunanetra. Anak tuna netra memerlukan pendampingan khusus dari orang tua, karena keterbatasan anak dalam melihat dapat mempengaruhi perkembangan fisik dan psikisnya.

Tuna netra merupakan suatu kondisi tidak berfungsinya indra penglihatan pada seseorang secara sebagian atau secara keseluruhan. Kondisi ini memerlukan tindakan yang tepat agar gangguan penglihatan tidak menjadi hambatan bagi perkembangan fisik dan psikisnya.

Data yang dipubllikasikan oleh Direktorat Jendral Rehabilitasi Sosial pada tahun 2010 pada akun resminya merilis peringatan World Sight Day yang jatuh pada tanggal 11 Oktober yang dilaksanakan pada tahun 2012 lalu, badan kesehatan dunia WHO merilis data bahwa setidaknya ada 40-45 juta penderita kebutaan. Pertahunnya tidak kurang dari 7 juta orang mengalami kebutaan atau permenitnya terdapat satu penduduk bumi menjadi buta. Survai indra penglihatan dan pendengaran tahun 1993-1996 menunjukan angka kebutaan di Indonesia $1,5 \%$ (paling tinggi di Asia) dibandingkan dengan Bangladesh $1 \%$, India $0,7 \%$ dan Thailand $0,3 \%$. Artinya jika ada 12 penduduk dunia buta dalam setiap 1 jam, empat diantaranya berasal dari Asia Tenggara dan dipastikan 1 orangnya dari Indonesia, survey ini juga disepakati oleh Direktur Jendral Bina Kesmas Kementrian Kesehatan RI, Budiharja. Berbagai data tersebut menunjukan banyaknya penderita gangguan penglihatan yang memerlukan penanganan yang cepat dan tepat.

Melihat merupakan faktor penting dalam kehidupan manusia. Anak usia 6-12 tahun (usia siswa sekolah dasar) masih berpikir konkret, pada periode ini anak hanya mampu berpikir dengan logika dan memecahkan persoalanpersoalan yang sifatnya konkret atau nyata saja, yaitu dengan cara mengamati atau melakukan sesuatu yang berkaitan dengan pemecahan persoalan-persoalan tersebut. "Bagaimana berpikir konkret yang dijalani oleh anak yang justru tidak dapat mengamati?" merupakan pertanyaan dalam benak penulis dan dirasa perlu untuk dikaji secara mendalam. Namun, seperti anak yang tidak mengalami gangguan disabilitas lainya, prestasi merupa-kan hal yang juga dapat diraih oleh anak penyandang tunanetra. Prestasi yang didapat para penyandang tuna netra tersebut dipengaruhi oleh dua faktor yaitu faktor yang berasal dari dalam (internal) dan faktor yang berasal dari luar (eksternal). Faktor yang berasal dari dalam antara lain intelegensi, motivasi, kepribadian, dan bakat. Faktor yang berasal dari luar antara lain lingkungan rumah, lingkungan sekolah, dan lingkungan masyarakat.

Hasil observasi peneliti pada guru dari siswa dengan riwayat yang sama (tuna netra berprestasi) di Kota Bogor menunjukan bahwa pola asuh orang tua merupakan faktor lingkungan rumah (eksternal) yang pertama dirasakan anak dan dominan berpengaruh terhadap prestasi belajar anak tuna netra.

Hal di atas menjadi latar belakang dalam penelitian ini yaitu pola asuh yang diterapkan orang tua pada anak 
tunanetra berprestasi. Salah satunya yang ditemui pada beberapa orang tua siswa tunanetra berprestasi di kota Bogor. Pola asuh ini perlu diperhatikan agar orang tua yang memiliki anak tuna netra dapat memberikan dukungan terbaik agar anaknya berprestasi. Pada penelitian ini, peneliti mengkaji lebih dalam pada pola asuh orang tua bagi anak tunanetra berprestasi.

Penelitian ini bertujuan untuk mengetahui bentuk pola asuh orang tua terhadap anak tunanetra berprestasi dengan orang tua siswa tunanetra berprestasi di Kota Bogor, sample diambil dengan cara mencari SLB-A (tunanetra) di kota Bogor dan mengambil siswa dengan raport terbaik dari masing-masing sekolah, diseleksi kembali dengan membandingkan nilai akhir raport siswa dari semua sekolah dan diambil nilai raport terbaik.

\section{Hakikat Pola Asuh}

Menurut Tafsir dalam Bahri [2] pola asuh berarti pendidikan. Dengan demikian pola asuh orang tua adalah upaya orang tua yang konsisten dan persisten dalam menjaga dan membimbing anak dari sejak dilahirkan hingga remaja.

Menurut Alfiana [3] pola asuh dapat diartikan sebagai corak atau model memelihara dan mendidik anak. Yang dimaksud pola asuh dalam penelitian ini yaitu sistem, cara atau pola yang digunakan atau diterapkan dalam kehidupan sehari-hari terhadap anak. Sistem atau cara tersebut meliputi cara mengasuh, membina, mengarahkan, membimbing dan memimpin anak. Pola ini tentu saja dalam setiap keluarga mempunyai pola yang berbeda antara satu keluarga dengan keluarga yang lainnya.

Menurut Papalia dalam Teviana dan Yusiana [4] pola asuh orang tua adalah suatu cara terbaik yang dapat ditempuh orang tua dalam mendidik anak sebagai perwujudan dari rasa tanggung jawab kepada anak. Peran keluarga menjadi penting untuk mendidik anak baik dalam sudut tinjauan agama, tinjauan sosial kemasyarakatan maupun tinjauan individu. Jika pendidikan keluarga dapat berlangsung dengan baik maka mampu menumbuhkan perkembangan kepribadian anak menjadi manusia dewasa yang memiliki sikap positif terhadap agama, kepribadian yang kuat dan mandiri, lmpotensi jasmani dan rohani serta intelektual yang berkembang secara optimal.

Menurut Djamarah [2] Anak siswa sekolah dasar (SD) adalah suatu masa dimana anak berada dalam rentang usia 67 tahun. Masa ini disebut masa matang sekolah. Pada masa ini anak sudah tertarik pada pekerjaan sekolah. Di samping itu, mereka pun memiliki kemampuan untuk mematuhi, mengikuti, dan menyelesaikan tugas-tugas sekolah. Tandatanda itu merupakan ciri kematangan untuk belajar.

Menurut Nasution dalam Djamarah [2] masa usia SD (sekolah dasar) sebagai masa kanak-kanak akhir yang berlangsung dari usia enam tahun hingga kira-kira sebelas atau dua belas tahun. Masa ini dikenal juga sebagai masa matang untuk belajar. Disebut masa sekolah karena anak sudah menamatkan TK (taman kanak-kanak) sebagai lembaga pesiapan bersekolah yang sebenarnya. Dalam masa ini anak sudah matang secara intelektual dan telah memasuki medan masa keserasian sekolah. Sebagai petunjuk anak matang secara intelektual.

Pola asuh orang tua adalah kebiasaan yang biasa dilakukan oleh ayah dan ibu yang diterapkan kepada anak dalam perkembangan-nya, berbagai bentuk pola asuh dapat diterapkan kepada anak, namun sangat bijak apabila pola asuh orang tua yang akan diberikan kepada anak disesuaikan dengan usia dan kemampuan anak. Sering kali ditemukan kesalahan yang sudah menjadi kebiasaan orang tua namun masih tetap dilakukan oleh orang tua. Informasi yang ditayangkan dalam pemberitaan yang dapat kita lihat di televisi masih sering menayangkan pola asuh orang tua yang tidak baik, dengan cara melakukan kekerasan fisik dan psikis anak, hal ini perlu dicermati dan dihindari. Tidak semua permasalahan dapat diselesaikan dengan membentak dan dengan hukuman fisik, orang tua perlu mencari alternatif lain agar maksud orang tua menyadarkan anak tidak salah sasaran, berupa dampak negatif yang ditunjukan oleh anak dari perlakuan orang tua yang salah tersebut.

\section{Hakikat Anak Tunanetra}

Menurut Kosasih [5] dalam bidang Pendidikan Luar Biasa, anak yang mengalami gangguan pengelihatan disebut anak tunanetra. Penggunaan istilah ini tidak hanya berlaku bagi mereka yang buta, melainkan mencakup juga mereka yang mampu melihat tapi sangat terbatas dan kurang dapat dimanfaatkan untuk kepentingan hidup sehari-hari terutama dalam belajar.

Menurut Kosasih [5] memiliki sikap tidak berdaya, sifat ketergantungan, memiliki tingkat kemampuan rendah dalam orientasi waktu, tak suka berenang, menikmati suara dari televisi, memiliki sifat kepribadian yang penuh dengan frustasi-frustasi, resisten terhadap perubahan-perubahan, cenderung kaku, dan cepat menarik tangan dari lawannya saat bersalaman, serta mudah mengalami kebingungan ketika memasuki lingkungan yang tidak familiar yang ditunjukan dengan perilaku-perilaku yang tidak tepat.

Tunanetra adalah suatu kondisi seseorang dengan keterbatasan melihat. Ada dua faktor yang dapat menyebabkan kondisi ini terjadi, yaitu faktor internal dan faktor eksternal. Faktor internal adalah faktor yang timbul dari penderita dan terjadi saat penderita masih ada dalam kandungan, contohnya karena usia kehamilan yang belum sempurna dan kelainan genetik. Faktor eksternal adalah faktor yang timbul di luar dari penderita dan terjadi pasca dilahirkan, contohnya kecelakaan yang merusak kornea mata. Tunanetra bukanlah alasan seseorang untuk berdiam diri dan tidak melakukan apapun, pada zaman sekarang ini sudah banyak tawaran yang coba diberikan medis untuk menangani kondisi ketunanetraan atau pun berbagai alat bantu yang diperuntukan untuk orang yang mengalami ketunanetraan

\section{Hakikat Prestasi Belajar}

Tingkat kecerdasan setiap individu berbeda antara satu dengan yang lainnya. Kecerdasan yang diperoleh diaktualisasikan dalam bentuk prestasi belajar. Menurut Sudjana dalam Gunawan [6] belajar adalah proses perubaha tingkah laku akibat interaksi individu dengang lingkungan. 
Perubahan itu mengandung pengertian yang luas, yakni pengetahuan, pemahaman, keterampilan, sikap, dan lain sebagainya atau yang lazim disebut dengan istilah kognitif, afektif, dan psikomotor. Penguasaan siswa terhadap pengetahuan (kognitif), nilai dan sikap (afektif), serta keterampilan (psikomotor) dengan baik menunjukan keberhasilan belajar yang telah dicapainya. Keberhasilan belajar inilah yang dalam dunia pendidikan dinamakan prestasi belajar.

Secara etimologis istilah prestasi merupa kan kata serapan dari bahasa Belanda yaitu dari kata prestatie, yang biasa diartikan sebagai hasil usaha, atau suatu hal yang telah dicapai, baik itu dilakukan ataupun dikerjakan. Dalam dunia pendidikan terdapat dua jenis prestasi, yaitu prestasi akademik dan prestasi belajar. Yang dimaksud prestasi akademik yaitu prestasi yang bersifat kognitif (cognitive) dan biasanya ditentukan melalui pengukuran dan penilaian. Prestasi belajar menurut Kamus Besar Bahasa Indonesia adalah penguasaan pengetahuan atau keterampilan yang dikembangkan oleh mata pelajaran, lazimnya ditunjukan dengan nilai tes atau angka nilai yang diberikan oleh guru.

Istilah prestasi belajar terdiri dari dua suku kata, yaitu prestasi dan belajar. Istilah prestasi di dalam Kamus Ilmiah Populer didefinisikan sebagai hasil yang telah dicapai. Noehi Nasution dalam Wahab [7] menyimpulkan bahwa belajar dalam arti luas dapat diartikan sebagai suatu proses yang memungkinkan timbulnya atau berubahnya suatu tingkah laku sebagai hasil dari terbentuknya respons utama, dengan syarat bahwa perubahan atau munculnya tingkah laku bukan disebabkan oleh adanya kematangan atau oleh adanya perubahan sementara karena suatu hal.

Gunawan [6] lebih menekankan indi kator prestasi belajar hanya pada satu ranah yaitu ranah kognitif. Menurutnya pengukuran perubahan tingkah laku seluruh ranah dirasa sangat sulit terutama ranah afektif. Hal ini disebabkan perubahan hasil belajar itu ada yang intangible (tak dapat diraba). Oleh karena itu, yang dapat dilakukan guru adalah hanya mengambil cuplikan perubahan tingkah laku yang dianggap penting dan diharapkan dapat mencerminkan perubahan yang terjadi sebagai hasil belajar siswa, baik dimensi cipta dan rasa maupun yang berdimensi karsa.

Berdasarkan kajian teoritik yang didapat maka ditarik kesimpulan mengenai pola asuh, tunanetra dan prestasi. Adapun kesimpulannya sebagai berikut. Pola asuh orang tua adalah kebiasaan yang biasa dilakukan oleh ayah dan ibu yang diterapkan kepada anak dalam perkembangannya, ada 15 Pola asuh pola asuh. Namun sangat bijak apabila pola asuh orang tua yang akan diberikan kepada anak disesuaikan dengan usia dan kemampuan anak. Sering kali ditemukan kesalahan yang sudah menjadi kebiasaan orang tua namun masih tetap dilakukan oleh orang tua. Dijumpai orang tua yang membentak dan memberikan hukum-an fisik pada anak, hal ini perlu dicermati dan dihindari. Tidak semua permasalahan dapat diselesaikan dengan membentak dan dengan hukuman fisik, orang tua perlu mencari alternatif lain agar maksud orang tua menyadarkan anak tidak salah sasaran, berupa dampak negatif yang ditunjukan oleh anak dari perlakuan orang tua yang salah tersebut.

\section{METODE PENELITIAN}

Metode penelitian ini dilaksanakan dengan metode studi kasus karena berangkat dari adanya masalah yaitu pola asuh orang tua anak tunanetra berprestasi.

Creswell dalam Herdiansyah [8] menyatakan bahwa studi kasus menekankan pada eksplorasi dari suatu "sistem yang terbatas" (bounded system) pada satu kasus atau beberapa kasus secara mendetail, disertai denga penggalian data secara mendalam yang melibatkan beragam sumber informasi yang kaya akan konteks

Data penelitian diperoleh dari sampel penelitian terhadap orang tua siswa tuna netra di kota Bogor dengan prosedur:

Tahap pra-lapangan

1. Menyusun rancangan penelitian

2. Memilih lapangan penelitian

3. Mengurus perizinan

4. Menjajaki dan menilai lapangan

5. Memilih dan memanfaatkan informan

6. Menyiapkan perlengkapan penelitian

7. Persoalan etika penelitian

Tahap pekerjaan lapangan

1. Memahami latar penelitian dan persiapan diri

2. Memasuki lapangan

3. Berperan-serta dan mengumpulkan data

Tahap analisis data

Membuat kesimpulan

Pengambilan data penelitian dilakukan di Kediaman Orang Tua Siswa yang Berlokasi Di Kampung Limusnunggal RT. 03/RW.05, Kelurahan Ciherang Pondok, Kecamatan Caringin, Kabupaten Bogor, dan di Sekolah Luar Biasa Al-Irsyad Al-Islamiyyah yang berlokasi di Jalan Sedane, Kampung Empang, Kelurahan Empang, Kecamatan. Bogor Selatan Kota Bogor.

Analisis data adalah upaya yang dilakukan dengan jalan bekerja dengan data, mengorgani-sasikan data, memilah-milahnya menjadi satuan yang dapat dikelola, mensintesiskannya, mencari dan menemu-kan pola, menemukan apa yang penting dan apa yang dipelajari, dan memutuskan apa yang dapat diceritakan kepada orang lain menurut Bogdan dan Biklen dalam Moleong [9].

\section{HASIL DAN PEMBAHASAN}

Orang tua merupakan peran penting pembentukan anak tunanetra berprestasi, Orang tua Anisah khususnya ibu Ium selalu mendampingi Anisah belajar bahkan memberikan pelajaran tambahan. Penelitian pun menunjukkan bahwa orang tua tidak hanya menerapkan satu pola asuh. Orang tua Anisah menerapkan beberapa pola asuh kepada Anisah, diantaranya pola asuh demokrasi, pola asuh laissez faire, pola asuh melebur diri, pola asuh manipulasi, pola asuh transaksi, pola asuh alih peran dan pola asuh konsultan. 
Banyak sekali pertimbangan orang tua Anisah untuk memberikan asuhan kepada Anisah. Mereka mempertimbangkan usia, kemampuan, lingkungan, kondisi Anisah mau pun kondisinya sendiri. Orang tua Anisah selalu memiliki alasan mengapa mereka menerapkan beberapa pola asuh, karena mereka tidak ingin anaknya mendapatkan asuhan yang salah. Menurut orang tua Anisah beberapa asuhan yang salah untuk diterapkan kepada anak khususnya yang mengalami ketunanetraan berupa pola asuh yang tidak memberikan kepercayaan kepada anak, terlalu membatasi anak sehingga anak kurang bisa berkembang dan tidak memiliki kepercayaan diri.

Anisah termasuk anak tunanetra yang tergolong setengah melihat atau low vision, pada awalnya orang tua Anisah tidak mengetahui kondisi Anisah tunanetra. Mereka baru mengetahui kondisi Anisah tunanetra setelah 40 hari terhitung setelah kelahirannya. Orang tua Anisah tidak melihat adanya gejala-gejala yang ditimbulkan dari tuna netra, tiba-tiba Anisah mengalami demam tinggi dan pandangan Anisah selalu melihat ke atas. Sudah banyak pengobatan yang dilakukan oleh orang tuanya kepada Anisah, namun tidak menunjukkan hasil. Akibat dari ketunanetraannya, orang tuanya menyekolahkan Anisah ke sekolah luar biasa agar Anisah mendapatkan penanganan yang tepat dari segi pendidikan.

Prestasi belajar Anisah sangat baik terbukti dengan nilai raport yang dimilikinya lebih baik dibandingkan degan nilai raport siswa tunanetra lainnya dari tiap-tiap sekolah. Potensi besar yang membentuk prestasi Anisah adalah asuhan orang tuanya. Banyak hal yang dilakukan oleh orang tuanya untuk Anisah, seperti mencari sekolah yang terbaik, mengikutsertakan Anisah les komputer dan pengajian, membimbing Anisah belajar, jemput-antar dan menunggu di sekolah.

\section{SIMPULAN}

1. Subyek sadar tentang potensi yang dimilikinya untuk membentuk prestasi anak. Subyek menerapkan beberapa pola asuh dengan berdasarkan pada beberapa pertimbangan diantaranya usia anak, kemampuan anak, lingkungan, serta kondisinya. Pola asuh yang diterapkan oleh subyek diantaranya pola asuh demokratis, pola asuh laissez faire, pola asuh melebur diri, pola asuh manipulasi, pola asuh transaksi, pola asuh alih peran, dan pola asuh konsultan .

2. Bentuk asuhan yang baik bagi anak tunanetra adalah asuhan yang meningkatkan kepercayaan diri anak, membangun ke-mandirian anak, dan menunjukkan kepedulian kepada anak.

3. Pola asuh orang tua sangat berperan penting dalam pembentukan prestasi anak, karena orang tua adalah orang yang paling dekat dengan diri anak. Waktu anak lebih banyak dilalui di rumah dibandingkan di sekolah, oleh karena itu, orang terdekatnya (orang tua) merupakan potensi besar yang membentuk prestasi belajar anak. Orang tua sudah sepatutnya menerapkan pola asuh yang mendorong, memberi semangat, mengasuh, dan membimbing anak-anaknya.

Hasil penelitian tentang pola asuh orang tua terhadap anak tunanetra berprestasi usia sekolah dasar menunjukkan pola asuh merupakan potensi besar yang membentuk prestasi anak tunanetra.

\section{Saran}

Bentuk pola asuh orang tua yang diterapkan kepada anak tunanetra berprestasi seyogyanya tidak hanya satu bentuk pola asuh, tetapi terdiri dari beberapa pola asuh yang bervariasi misalnya pola asuh demokrasi, pola asuh laissez faire, pola asuh melebur diri, pola asuh manipulasi, pola asuh transaksi, pola asuh alih peran dan pola asuh konsultan.

\section{REFERENSI}

[1] Y. Suchyadi, "Relationship between Work Motivation and Organizational Culture in Enhancing Professional Attitudes of Pakuan University Lecturers," vol. 01, no. 01, 2017.

[2] S. B. Djamarah, Pola Komuni-kasi Orang Tua dan Anak dalam Keluarga. Jakarta: Rineka Cipta, 2015.

[3] Ester Alfiana N, Pola Asuh Orang Tua Terhadap Anak Dalam Keluarga Pada Bidang Pendidikan Di Dusun Pandanan Desa Pandanan Kecamatan Wonosari Kabupaten Klaten. Yogyakarta: Fakultas Ilmu Sosial, Universitas Negeri Yogyakarta, 2013.

[4] F. Teviana and M. A. Yusiana, "Pola asuh orang tua terhadap tingkat kreativitas anak," J. STIKES, vol. 5, no. 1, pp. 48-60, 2012.

[5] Kosasih, Cara Bijak Memahami Anak Berkebutuhan Khusus. Bandung: Yrama Widya, 2012.

[6] Gunawan, Pendidikan Ekonomi. Lampung: Fakultas Ilmu Pendidikan Sosial, Universitas Lampung, 2013.

[7] A. Wahab, Psikologi Suatu Pengantar Dalam Perspektif Islam. Jakarta: Permada Media, 2016.

[8] Herdiansyah, Metodologi Penelitian Kualitatif untuk Ilmu-Ilmu Sosial. Jakarta: Salemba Humanika, 2011.

[9] Moleong, Metodologi Penelitian Kualitatif. Bandung: PT Remaja Rosdakarya, 2011. 